\title{
BRALNE NAVADE STARŠEV \\ IN VZPODBUJANJE
PRI BRANJU
}

Marija Horvat, spec. šol. ped.

\section{POVZETEK}

V prispevku sem razmejila pojma vseživljenjsko izobraževanje in vseživljenjsko učenje, ki je bolj populističen izraz. Za vsakega posameznika sta vseživljenjsko izobraževanje in vseživljenj.sko učenje zelo pomembna, saj se ne končata s formalnim šlanjem, pač pa potekata celo življenje. Kakšne možnosti izobraževanja imajo deprivilegirane skupine zaradi socialnih, psiholoških, kulturnih in ekonomskih razlogov? Tuji avtorji - Freire, Gramschi, Jarvis, Delors - poudarjajo moč izobraže vanja za napredek družbe, spremembo miselnosti in odnosov ned ljudmi. Raziskave kažejo veliko zaostajanje Slovenije na področju pismenosti v primerjavi z razvitimi državami Evrope in Amerike. Ker je stopnja pismenosti otrok v korelaciji s stopnjo pismenosti staršev oz. izobrazbe staršev, smo lahko opravičeno zaskrbljeni, saj so starši, ki dosegajo višje rami pismenosti, dejavnejši pri prenašanju bralniln navad in bralne kulture na svoje otroke in je tako pismenost lahko tudi podaljs̆ana roka družine, starši pa pomemben dejavnik pri razvoju delovnih in bralnih navad svojih otrok.

Študije primerov devetih orrok in staršev prikazujejo oz. potrjujejo dejstvo, da se v večini primerov izobraževanje in branje staršev neha sormalnim izobraževanjem. Bralne navade so vezane le še na informativno branje dnevnega časopisja. Skrb za branje starši v veliki meri prepušc̆ajo iniciativi otrok in pobudam šole ter učiteljev. To prednost šole in zaupanje učiteljem bi bilo potrebno izkoristiti z uvedbo bralnih krožkov, s prosvetljevanjem staršev preko predavanj in roditeljskih sestankov, vsekakor pa učence učiti aktivnih strategij učenja in branja, ki jih bodo lahko uporabljali tudi pozneje kot odrasli pri vseživljenjskem učenju.

Ključne besede: bralne navade, starši, otroci

$\mathrm{V}$

prispevku bom opisala kvalitativno raziskavo, ki sem jo opravila v tretjem razredu OŠ Miška Kranjca Velika Polana. Starše devetih otrok sem povabila $\mathrm{k}$ izvedbi intervjuja in jih povprašala o njihovih bralnih navadah. Rezultate bom primerjala $z$ bralnimi dosežki učencev in tako sklepala, kako starši svoje otroke vzpodbujajo $\mathrm{k}$ branju. Iz raziskave bom lahko sklepala tudi o permanentnem izobraževanju odraslih oz. vseživljenjskem izobraževanju, ki poteka celo življenje in se ne konča s koncem formalnega, šolskega izobraževanja.

\section{VSEŽIVLJENISKO \\ IZOBRAŽEVANIE IN VSEŽIVLJEN]SKO UČENIE}

Strokovna razprava avtorjev $v$ publikaciji Vseživljenjsko izobraževanje in vseživljenjsko učenje (1998) sicer razmeji termina vseživ- 
ljenjsko izobraževanje in vseživljenjsko učenje, vendar $v$ laičnih krogih razlike niso tako opazne, zato se oba izraza $v$ javnosti še vedno uporabljata. Za strokovnjake in znanstvenike $v$ izobraževalnih vedah pa je enačenje obeh pojmov nesprejemljivo, ker med njima obstajajo pomembne razlike (Krajnc v Vseživlienjsko, 1998). Izobraževanje je bolj strukturiran proces pridobivanja znanja in zato tudi bolj obvezujoč za politiko nekc državc, učenje pa je bolj ohlapno in tako manj zavezujoče, zato so ga tudi posvetne oblasti veliko bolj vzele za svojega (Vseživljenjsko, 1998). Tudi v literaturi sta prisotna oba izraza. Vseživljenjsko učenje je bolj populističen izraz, saj ljudje raje vidijo, da se učijo kot izobražujejo. Zaradi pluralnosti $v$ izobraževanju uporaba obeh izrazov ni moteča - odvisno od tcga, kaj hočc oseba poudariti -, torej vseživljenjsko izobraževanje in vseživljenjsko učenje (Krajne $v$ Vseživljenjsko, 1998).

\section{ALI IMAJO LJUDJE RES ENAKE IZOBRAŽEVALNE MOŽNOSTI?}

Že prva točka 26. člena Splošne deklaracije človekovih pravic se glasi: Vsakdo ima pravico do izobrazbe. Izobraževanje je brezplačno vsaj na začetni in temeljni stopnji. Šolanje na začetni stopnji je obvezno. Tehnično in poklicno šolanje mora biti splošno dostopno. Višje šolanje mora biti na osnovi doseženih uspehov vsem dostopno (Kodelja v lzobraževanje odraslih, 1999). Enaká dostopnost pomeni, da imajo vsi člani skupnosti možnost nadaljevati šolanje po svojih sposobnostih.

$\mathrm{V}$ sodobnih industrijskih in postindustrijskih družbah, kjer je prevladovala liberalna ideologija enakosti, so se začeli tudi procesi za enaka izhodišča za izobraževanje za vse udeležence izobraževanja. Odstraniti je bilo potrebno vse ovire ekonomskega, socialnega, kulturnega in geografskega značaja. Tudi na področju izobraževanja mora imeti vsak enake možnosti, da obiskuje šolo. V svetu je bilo kar nekaj primerov zagotavljanja enakih izhodišč in uvajanja kompenzacijskih programov (ZDA, Poljska, SZ).

Kodelja (v Vseživljenjske), 1999) opozarja na rezultate raziskav, da dvig izobrilževalnih možnosti ne vodi tudi $\vee$ zmanjšcvanje socialnih razlik, saj vsem ljudem, kljub višji izobrazbi, ni mogoče zagotoviti dobro plačanih delovnih mest.

\section{PROTISLOVNA VLOGA IZOBRAŽEVANJA}

Ob naporih enake dostopnosti izobraževanja in doseganja rezultatov $v$ skladu $s$ sposobnostmi vsakega posameznika je bila ravno ambicija po preseganju socialnih razlik in socialno vključevanje eden najprotislovnejših ciljev v razvoju množičncga izobraževanja (Ule v Vseživljenjsko, 1999). Ob tiendih vključevanja se je vseskozi dogajalo socialno razlikovanje oziroma izključevanje tistih, ki se zaradi socialnih, psiholoških, kulturnih in ckononskih razlogov niso mogli vključevati $v$ podaljšsano izobraževanje in $v$ zahtevnejše oblike izobraževanja. To je vnašalo številna protislovjá.

Javna ideologija poudarja demokratičnost, neformalni, skriti kurikulum v šolah pa je poudarjal obstoječe družbene razlike in navajal Jjudi na kvalitativno različne življenjske poti in družbene položaje. Tako je moderno izobraževanje še proizvajalo družbene razlike, námesto da bi jih blažilo (Ule $\vee V$ seživljenjskso, 1999).

Drug izvor nasprotij je bil v napetosti med izobraževanjem in vzgajanjem. Vzgojna funkcija šole se je vse bolj umikala izobraževalni in še ta, kj je ostala, je sililá k ideološkim znalčajem vladajoče strukture. Zaradi omejenosti izobraževanja le na otroško in mladostniško dobo se je $v$ izobraževanje odraslih prav malo vlagalo. Izstopanje iz delovnega procesa in vračanje $v$ izobraževanje pa je bilo bolj izjema kot pravilo. 
Freire meni, da učenje lahko posameznika zavira ali osvobaja. Gramschi in Freire postavljata $v$ ospredje transformativno izobraževanje odraslih. Teorija transformativnega izobraževanja predstavlja poskus spremembe temeljev sistema in ne zdravljenje simptomov. Osnovna teorija Gramschija in Freira je uvesti oziroma razviti tak način izobražcvanja, ki ga lahko približamo deprivilegiranim skupinam. Izobraževanje narediti dostopno vsem, saj je $v$ izobraževanju moč, torej vključitev uddi deprivilegiranih, ki jih šolski sistem $s$ prikritim kurikulumom in neformalnim odnosom še bolj utrjuje

Tudi Freire in Gramschi vidita izhod v bitki proti sistemskim, strukturnim in simbolnim oblikam zatiranja. Prepričana sta, da igra izobražcvanje odraslih pomembno vlogo pri sodelovanju v tej bitki. Če se izobražuješ, si sposoben sodelovati pri družbenih spremembah oziroma pri odpravljanju različnih oblik Zatiranjal s strani države in ostalih institucij in sistemov. Oba avtorja se ne zavzemata zá šolski in institucionalni način učenja, ampak za liberalni, kjer se posameznik nauči analizirati sistem, gledati nanj kritično in se naučiti iskati novih poti, s katerih lahko gleda na stvari.

Tudi Jarvis (1997) poudarja, da se v izobraževanju izgublja osnovna vrednota, to je sodelovanje, družcnje med ljudmi, medosebni odnosi. Jarvis tudi pravi, da danes, v obdobju globalizacije, postaja razvita tehnologija vir informacij, ki preskoči izobraževanje in se informacije prenesejo neposredno $k$ učečim se, tudi $k$ odraslim. Delovne organizacije same zase organizirajo izobraževanja - tako je izobraževanje postalo dostopno vsem ljudem. Ti pa morajo poučevati in navduševati za spre membe tudi druge, kajti brez izobražcnih ljudi ni družbene spremembe.

Postmoderna družba je družba, ki izraža željo po učenju in tako jo lahko imenujemo tudi učeča se družba. Taka družba prinaša tudi spremembo miselnosti in političnega reda. Jarvis (1997) ugotavlja, da iz šolstva in izobraževanja izginja osnovna univerzalna vrednota - biti pozoren do drugih in skrbeti za soljudi. Velik pomen daje učiteljem, ki bodo edini lahko uresničili pomoč vsakemu posamezniku, kar bo vzpodbuda za doseganje ciljev in hkrati spreminjanje družbe.

\section{PISMENOST V SLOVENIJI}

Andragoški center Slovenije je leta 1998 izpeljal nacionalno raziskavo pismenosti odraslih, skupaj z 22 drugimi državami. Rezultati so pokazali veliko zaostajanjc Slovenije za razvitimi državami Evrope in Amerike na področju pismenosti, saj se je večina odraslega prebivalstva v Sloveriji po pisnih dosežkih umestila na najnižje ravni pismenosti. Postavlja se vprašanje, kako bo lahko država s tako nizkim človeškim kapitalom zagotavljala blaginjo in gospodarski razvoj

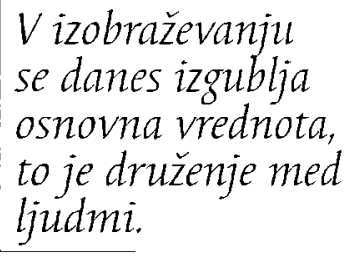
$\checkmark$ informacijski družbi, ki temelji na znanju (Možina v Pismenost, 2000). Ker je od kakovosti zaloge kapitala izobrazbe močno odvisna gospodarska uspešnost posameznih držav, lahko to razumemo kot posredni kazalec naše uspešnosti.

Pismenost je v življenju ljudi zelo pomembna, tako se na delovnem mestu nenehno srečujemo $z$ različnimi, povečini tiskanimi informacijami, število virov pa se povečuje. Tako v zasebnem kot tudi delovnem okolju moramo izbirati med različnimi viri, da se lahko pravilno odločamo, izpeljemo nakup, poiščemo službo, odpremo račun ali gremo na počitnice (Možina v Pismenost, 2000).

Od tega, koliko smo pismeni, je $v$ precejšnji meri odvisno tudi, koliko bomo uspešni pri različnih vlogah, ki jih opravljamo v življenju (kot starši, delavci, državljani ...). 
Pisni dosežki pa se odražajo na trgu dela tako na ravni posameznika kot tudi na ravni države.

\section{VPLIV IZOBRAZBE STARŠEV}

Raziskave kažejo, da je stopnja pismenosti otrok v korelaciji s stopnjo pismenosti staršev oziroma izobrazbe staršev - dostopnost do knjig, revij, časopisov ... (Kroflič v Pis. menost, 2000). Nižje ravni pismenosti dose-
Stopnja pismenosti otrok je $v$ tesni povezavis pismenostjo staršev. gajo posamezniki iz družin $z$ nižjimi stopnjami izobrazbe in obratno. Stopnja izobrazbe staršev je pomembna za razvoj pismenosti pri posamezniku, kajti tisti odrasli, ki sami dosegajo višje ravni pismenosti, so dejavnejši tako pri prenašanju bralnih navad in bralne kulture na svoje otroke, kakor tudi pisnih praks, ki so bližje šolskim in tako olajšajo otrokom vstop v šolo. Pismenost se tako kaže kot podaljšana roka družine (Možina $\vee$ Pismenost, 2000).

Odrasli jo ohranjajo tudi z uporabo na delovnem mestu. Prav tako je potrebno redno branje in pisanje ne le za učenje novih spretnosti, temveč tudi za ohranjanje pridobljenih kar pomeni, da če pisnih spretnosti ne uporabljamo redno, počasi usahnejo.

Tisti, ki pogosto berejo, dosegajo višje ravni

Primeri dobre prakse šol so: organizacija dneva odprtih vrat na temo branje, sodelovalno branje, svetovalnice za branje, tekmovanje $v$ branju, pravljično-literarne uganke, branje $v$ nadaljevanjih, iskanje skritega zaklada, knjižni kvizi, razstave, teden knjige, družinsko branje, praznovanje z literaturo - praznik črk, branje za dobro jutro, branje $z$ medvedkom, obiski vaške in mestne knjižnice s pravljičnimi urami, bralni kotički, prostovoljna pomoč staršev, dijakov, študentov, nabava knjig po izbiri otrok, vsakodnevno 15-minutno branje, razni projekti na temo branja, babica mi bere in se pogovarja $z$ mano, šola za lepe besede, dišeča abeceda ... (Vzgoja, št. 20, 2003, in Različne vrste branja, 2001) pismenosti in obratno. Prav branje je veščina, ki vzdržuje oziroma krni raven pismenosti pri ljudeh. Od pismenosti odraslih je odvisna tudi kakovost šolskega učenja, ki je še vedno vse preveč transmisijska in premalo vczana na lastno aktivnost učencev, na procesno učenje, transfer, učenje strategij, sodelovalno učenje in tudi na čustveno motivacijske in socialnosituacijske dejavnike (Barica Marentič Požarnik v Pismenost, 2000).

\section{BRANIE ZA ŽIVLIENJE}

Da bi vzgojili bralca za vse življenje - bralca kot uspešnega učenca, ki bo pripravljen na vseživljenjsko učenje, je trud učiteljev in delo na šoli premalo. Čeprav poučevanje branja starši $v$ glavnem prepuščajo šoli, se moramo zavedati, da je razvoj bralca $\vee$ resnici odvisen od tega, kar se dogaja doma, $v$ družini. Šola je staršem pri vzgoji otroka le v pomoč in podporo. Na področju branja pa je naloga šole predvsem ta, da začete sposobnosti pomaga razvijati. V kolikšni meri izpolnjuje ta izziv, je seveda odvisno tudi od učiteljev, knjig, ki jih uporablja, in seveda tudi metod poučevanja branja. Šola naj se trudi od učencev dobiti toliko, kolikor so sposobni. To pa zmore le ob podpori in sodelovanju staršev (Horvat, 2003)

\section{ŠTUDIJA PRIMEROV}

Na OŠ Miška Kranjca Velika Polana sem opravila vodene intervjuje $z$ devetimi starši učencev 3. razreda. Vzorec sem izbrala naključno (vsak drugi učenec). Staršem sem zastavila nekaj vprašanj o branju, s katerimi sem želela ugotoviti, kaj berejo starši, kako pogosto berejo, koliko knjig prebcrejo na leto, zakaj berejo, kako pogosto obiščejo knjižnico, kako pogosto kupijo kakšno knjigo in kako vzpodbujajo svoje otroke k branju. Vprašalnik je v prilogi.

Rezultate vprašalnika sem primerjala tudi z 


$$
\text { 壾 }
$$




\section{Učenka 2}

Učenka 2 ima oceno iz slovenščine prav dobro. Razgovora se je udeležila mama. Stara je 42 let. Končala je osnovno šolo in je zaposlena. Povedala je, da oče nima časa priti na razgovor. Mama najpogosteje bere revije: Jana in Lady ter časopise: Vestnik, Nedeljski. Knjige, ki jih prebere, so šolsko čtivo, saj jih najprej prebere mama, nato pa hčerka. Oče nima časa za branje. Najpogosteje berejo ob koncu tedna in zvečer, pred spanjem. Mama je v zadnjih dveh letih prebrala $15-20 \mathrm{knjig}$. Oče se je ob delu izobraževal in ni imel časa za branje. Berejo zato, da izvejo nove stvari. V šolski knjižnici so že bili, vendar niso vzeli knjig. Knjigo le redko kupijo, morda eno do dve na leto. Dosti knjig si sposodijo v knjižnici. Mama je v zadnjem letu prebrala Hišo čarovnic avtorice Vjktorije Holt in šolsko gradivo za domače branje svoje hčerke. Učenká 2 sama skrbi za svoje branje. Vesela je, če jo starši pri tem vzpodbujajo. Oče rad reče: Več prebereš, več veš. Mama je še povedala, da hčerka rada bere, da $v$ enem tednu prebere $1-2$ knjigi in da nima težav $z$ branjem.

\section{Učenka 3}

Učenka 3 ima oceno iz slovenščine odlično. Razgovora se je udeležila mama. Stara je 46 let, končala je osnovno šolo in ni zaposlena, dela doma na kmetiji. Najpogostcje berc časopis (Novice, Večer) in knjige, ki jih hčerka prinese iz šole. Rada bere njene knjige, saj ji tako lahko pomaga pri šolskem delu. Doma berejo vsak dan. $V$ zadnjih dveh letih je mama prebrala 10 ali več knjig. Bere zato, da je na tekočem s stvarmi. Sama še ni obiskala knjižnice, saj jo otroci zalagajo s knjigami. Redko kupijo kakšno knjigo - eno do dve na leto. Mama je v zadnjem letu prebrala knjige: Harry Potter, Lukec in njegov škorec, Skrivni dnevnik ... Učenka 3 sama bere, tudi mama jo vzpodbuja z lastnim branjem, želi pa tudi, da ji pove, o čem je brala. Za osnovno šolo se bolj zanima mama, oče pa je prevzel nadzor nad srednjo šolo. Mama je povedala, da je dobro brati, saj škoditi ne more.

\section{Učenka 4}

Učenka 4 ima oceno iz slovenščine prav dobro. Razgovora se je udeležil oče. Star je 33 let. Po poklicu je strojni tehnik, ukvarja in preživlja pa se z gostinstvom. Doma najpogosteje berejo časopise (Novice in Sportske novosti). Od knjig najpogosteje berejo romane. Največ časa za branje imajo na morju. Oče je povedal, da je največ bral pri vojski. Pogosto bere takrat, ko ima čas in nima drugih obveznosti. $V$ zadnjih dveh letih ni prebral nobene knjige. Časopise bere predvsem zato, da izve nove stvari in je na tekočem. Krajevno knjižnico jc žc večkrat obiskal. Knjigo zelo redko kupijo. Svojo hčerko vzpodbuja k branju tako, da ji reče, naj bere, in da mu pripoveduje o vsebini knjige. Včasih ji tudi kupi kakšno knjigo. Povedal je, da je zadovoljen z branjem svoje hčerke.

\section{Učenka 5}

Učenka 5 ima oceno iz slovenščine prav dobro. Za učenko 5 sta sc razgovora udelcžila oba starša, vendar je glavno besedo imela mama. Mama je stara 30 let, opravljen ima tečaj sobarice, je brez zaposlitve. Oče je star 28 let, končal je poklicno šolo in dela v pekarni. Doma berejo predvsem časopis Novice in razne revije: Lisa, Cosmopolitan, Lady. Mamo predvsem zanimajo zdravstveni vodniki in zdravilne rastline, očeta pa knjige 'naredi sam'. Casopise in revije berejo vsak dan, knjige pa občasno, ko nimajo drugih obveznosti. $V$ zadnjih dveh letih sta oba starša prebrala po tri in več knjig. Berejo predvsem zato, da izvejo nove stvari. Krajevne knjižnice $v$ šoli še niso obiskali. Letno kupijo do 4 knjige. $V$ zadnjem letu je oče prebral knjigo Sam svoj mojster in otroške pravljice. Mama pa je prebrala naslednje knjige: Rada pleše, rada ima glasbo, Čarovnica Lili, 5 prijateljev ter Ženski vodnik. Oba sta povedala, da vča- 
sih kakšno knjigo večkrat prebereta. Svojo hčerko vzpodbujata z lastnim branjem, žclita, da jima o prebrani knjigi poroča, včasih pa ji tudi kupita kakšno knjigo. Povedala sta tudi, da je vedno manj časa za branje, da ima pri branju velik vpliv televizija, vendar je zanju knjiga bolj zanimiva kot film. Njuna hčerka rada bere, poje, njena sedanja odločitev pa je, da bo postala pisateljica. To jo tudi zelo motivira pri učenju.

\section{Uěenec 6}

Učenec 6 ima oceno iz slovenščine prav dobro. Za učenca 6 je na razgovor prišla mama. Mama je stara 31 let, končala je osnovno šolo in je zaposlena $v$ tekstilni industriji. Najpogosteje bere revijo Lady. Oče bere revije s tehnično vsebino. Bercjo ponavadi zvečcr. $V$ zadnjih dveh letih je mama prebrala 5 knjig za otroke. Bere zato, ker jo to veseli. Občasno obišče krajevno knjižnico v šoli. Knjig doma ne kupujejo. V zadnjem letu je mama prebrala knjige, ki jih je otrok prinesel iz šole. Doma učenca vzpodbujajo tako, da mu rečejo, naj bere, sicer pa učenec 6 rad bere.

\section{Učence 7}

Učenec 7 ima oceno iz slovenskega jezika prav dobro. Razgovora se je udeležil oče. Star je 42 let. Končal je srednjo tehniško šolo in je zaposlen v elektroindustriji. Mama ima VI. stopnjo izobrazbe in je zaposlena na telekomunikacijah.

Oče najpogosteje bere revije in časopise (Večer, Nedeljski dnevnik, Vestnik, Stop). Mama. bere predvsem romane. Običajno berejo zvečer, ob koncu tedna in to bolj pozimi, ko mama $v$ dveh dneh prebere eno knjigo. Oče zaradi pomanjkanja časa prebere $v$ dveh letih le kakšno knjigo alli dve. Oče bere predvsem tehnične stvari in strokovno literaturo iz veselja in potrebe. Izpolnjuje se tudi $v$ angleščini. Mama bere predvsem razne zgodbe $v$ knjigah. Krajevnc knjižnice v šoli nc obiskujejo, saj mama prinese knjige iz knjižnice $v$ Len-

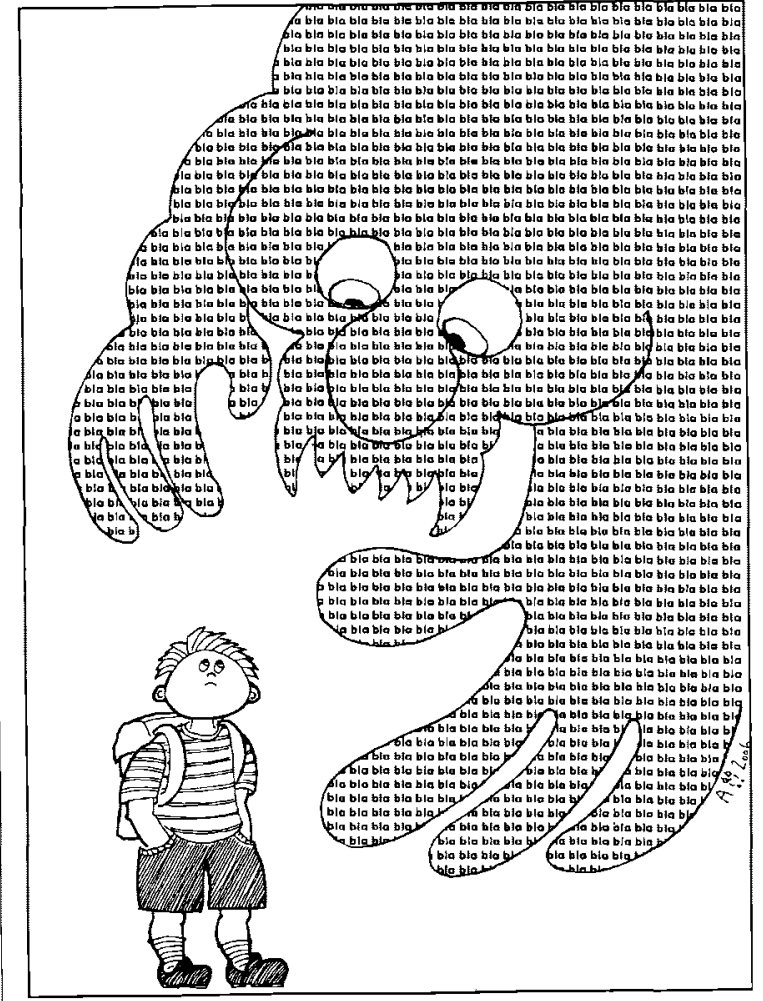

davi. Doma kupijo približno 4 knjige na leto in to predvsem leksikone, priročnike in druge uporabne knjige, $\mathrm{ki}$ jih otroci potrebujejo za šolo. Kaij so prebrali y zadnjem letu, sc oče ni spomnil, povedal pa je, da so to bili razni romani in strokovnc knjige. Oče je povedal, da se učenju $v$ šoli bolj posveča mama. $\mathrm{Za}$ učenca 7 je branje bolj prisila, saj mu je bolj kot knjige ljubši računalnik. Za branje mu je potrebno veliko prigovarjati. Zelo rad rešuje križanke.

\section{Učenec 8}

Učenec 8 ima oceno i2 slovenščine dobro. Razgovora se je udeležil oče. Star je 37 let,

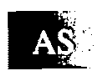


končano ima poklicno šolo, zaposlen pa je kot samostojni podjetnik. Najpogosteje bere čisopis (Vestnik in Večer). Vestnik bere tedensko, Večer pa le občasno. V zadnjih dveh letih je prebral tri ali več knjig. Oče bere, ker je rad na tekočem s stvarmi. Pravi, če več bereš, več znaš. Krajevne knjižnice v šoli ne obiskuje,

$Z$ branjem in $s$ šlsko uspešnostjo se najpogosteje ukvarjajo matere. saj ima dovolj branja doma in tudi časa ni za to. Čez leto kupi le kakšni dve do tri knjige. $V$ zadnjem letu je prebral kar nekaj pustolovskih knjig. Oče je povedal, da mama bolj spremlja branje za bralno značko. Mama je tudi sicer zadolžena za branje otroka in gà vzpodbuja tako, da z njim bere, predcla vsebino. Očc je bolj zadolžen za matematiko. Branje otroka je zadovoljivo, zaveda se, da bi lahko bilo boljše, bolj gladko, vendar takšne probleme rešujejo pozimi, ko je več časa.

\section{Učenec 9}

Učenec 9 ima oceno iz slovenščine zadostno. Učenec živi sam z očetom, saj mu je mama umrla. Oče je star 42 let, končano ima IV. stopnjo izobrazbe in je zaposlen $v$ strojništvu. Najpogosteje bere časopis Novice. Bere predvsem ob koncu tedna. Knjig ne bere, ker nima časa. Časopis bere zaradi zanimivosti in TV sporeda. Knjižnice ne obiskuje in ne kupi nobene knjige. $V$ zadnjem letu ni prebral nobene knjige, sicer pa otroka vzpodbuja, naj vadi vsak dan, da bo bolje razumel. Oče pravi, da se otrok včasih sam spomni na branje, včasih ga mora opomniti. Ima težave $z$ branjem, saj ne bere gladko, zato ne razume. Več časa imata med počitnicami. Oče pravi, da je čas največje vprašanje.

\section{ANALIZA REZULTATOV VPRAŠALNIKA}

se razgovora udeležila oba starša. Z branjem in s šolsko uspešnostjo se najpogosteje ukvarjajo mame. Očetje prevzemajo odgovornost za nadaljnje šolanje otroka. Iz vprašalnikov lahko razberemo, da starši berejo predvsem dnevno časopisje in revije, po knjigah sežejo le nekateri.

Tudi čas branja je razporejen glede na čas. Revije in časopise berejo vsak dan, sicer pa zvečer ali ob koncu tedna, ko nimajo drugih obveznosti.

$V$ zadnjih dveh letih je največ staršev prebralo tri ali več knjige le $v$ dveh družinah preberejo od 10 do $20 \mathrm{knjig}$, v dveh primerih pa knjig sploh ne berejo.

Starši berejo nájpogosteje zato, da izvejo nove stvari in da so na tekočem. Knjižnice $v$ šoli večinoma ne obiskujejo, knjige jim preskrbijo šolarji, poslužujcjo pa se tudi knjižnice $v$ Lendavi oz. Murski Soboti. Knjige kupujejo iz potrebe po poklicnem izobraževanju ali kot darilo otrokom. Dva starša se tudi dodatno izobražıjeta za službene potrebe. Zanimivo je, da starši pogosto berejo knjige, ki jih učenci obravnavajo $v$ šoli, da jim potem lahko pomagajo pri delu $v$ šoli. Vzpodbude za branje v nekaj primerih prepuščajo učencem samim in njihovi iznajdljivosti, nekaj jih motivirajo z lastnim branjem, s prepričevanjem in tako, da jih povprašajo o vsebini. Branje je vsekakor povezano s šolskim delom, zato starši napredovanje $\vee$ veliki meri prepuščajo šoli, iniciativi in iznajdljivosti učiteljev ter lastnim interesom otroka.

Uspešnost otrok v šoli (ocena pri slovenskem jeziku) ni odvisna od socialnega statusa družine, saj imajo učenci $v$ glavnem oceno prav dobro ali odlično. Le en učenec ima oceno dobro oz. zadostno. Ta slabša ocena je posledica pomanjkljivosti na učnem in socializacijskem področju. Otrok je po odločbi komisije za usmerjanje dobil dodatno učno pomoč, prav tako pa tudi pomoč javne delavke pri vključevanju v obogatitvene programe šole in okoljia. 


\section{SKLEPNA MISEL}

Iz prikazanega lahko razberemo, da starši branju ne posvečajo posebne pozornosti in ne gojijo posebne bralne kulture. Razvoj branja prepuščajo otrokovi iznajdljivosti in vzpodbudam šole. Pri šolskem delu jim pomagajo in želijo, da so učenci uspešni. Mislim, da bi večja zavzetost staršev do branja in bralne kulture učencem omogočala doseganje boljših rezultatov, večje ambicije ter doseganje višjih ciljcv. Mislim, da je branje v večini primerov vezáno le na šolsko obdobje, po formalnem izobraževanju pa se branje iz takšnih ali drugačnih razlogov opušča oz. omcjujc le na informativno branje dnevnega časopisja in revij, razen nekaj izjem. Tudi odziv staršev kaže na to, da niso ravno pripravljeni govoriti o svojih bralnih navadah. To sem lahko opazila tudi pri vodenju samega intervjuja. $\mathrm{Ne}$ kateri odgovorov niso želeli komentirati. Največkrat je bil v opravičilo omenjen čas, ki jim ne dopušča branja.

$\mathrm{V}$ uvodu zlasti Jarvis omenja pomanjkanje medosebnih odnosov med ljudmi in daje velik vpliv prav učiteljem, ki pri tem lahko odigrajo pomembno vlogo. Zelo zanimivo bi bilo uvesti bralne krožke, ki bi omogočali branje in tudi medosebno komunikacijo. Tako bi tudi odrasli oz. starejši ljudje ohranjali svojo kognitivno vitalnost, ki z leti ne upada, ampak jo s svojo psihofizično aktivnostjo vedno znova in znova obnavljamo (Krajnc, 2003). Učitelji pa imajo tudi drugo možnost izobraževanja in prosvetljevanja staršev preko raznih srečanj, delavnic, roditeljskih sestankov, govorilnih ur in drugega projektnega dela, ki omogoča osebnejši stik in sodelovanje staršev in otrok. Kako pa doseči permanentno izobraževanje, ki naj se ne konča s formalnim izobraževanjem? Morda je sedaj pravi čas dela $z$ učenci $\checkmark$ šoli. Kot pravi B. Marentič Požarnik, naj izobraževanje ne bo le transmisija ali prenašanje znanja, pač pa tudi učenje strategij, sodelovalno učenje, lastna aktivnost učen- cev, povezana s čustveno socializacijskimi in motivacijskimi dejavniki, ki jih bodo učenci pozneje kot odrasli uporabljali tudi pri vsě̌ivljenjskem izobraževanju.

\section{LITERATURA}

Velikonja M. (ur.) (1999). Izubriľ̌vanje odraslih, socialna meenakost in socialna vključenost. Ljubljana: Anuragoški center.

Jelenc, Z. (ur:) (1998). Vseživljenjsko izobraževanje in vieživljenjsko učenje. Ljubljana: Andagoški center.

Velikonja, M. (ur.) (1999). Pismenost, participacija in družba znanją. Andragoški kolokvij. Ljubljana: Andragoški cente:

Ivšek, M. (ur.) (2001). Različne vrste branja terjajo aazvijanje različnila bralnih strategij. Ljubljana: ZRSŠ.

Mayo, P. (1998). Gramschi, Freire and Adult Education. London, New York: Zed Books.

Jarvis P. (1997). Ethics and education for adults in a late modern society. Niace.

Horvat, M. (2003). Branje za življenje. Vzgoja, št. 20. Krajnc, A. (2003). Sposobnosti odlaslih in učljivost. Ljubljana: Filozofska fukulteta 